\title{
Host-parasite relationship of Ortholinea lauquen sp. nov. (Cnidaria: Myxozoa) and the fish Galaxias maculatus in northwestern Patagonia, Argentina
}

\author{
G. Alama-Bermejo ${ }^{1,2, *}$, G. P. Viozzi ${ }^{3}$, M. A. Waicheim ${ }^{3}$, V. R. Flores ${ }^{3}$, S. D. Atkinson ${ }^{4}$ \\ ${ }^{1}$ Centro de Investigación Aplicada y Transferencia Tecnológica en Recursos Marinos Almirante Storni \\ (CIMAS-CCT CONICET-CENPAT), 8520 San Antonio Oeste, Río Negro, Argentina \\ ${ }^{2}$ Institute of Parasitology, Biology Centre of the Czech Academy of Sciences, 37005 České Budějovice, Czech Republic \\ ${ }^{3}$ Instituto de Investigaciones en Biodiversidad y Medio Ambiente (INIBIOMA: CONICET-UNCo), 8400 Bariloche, Río Negro, \\ Argentina \\ ${ }^{4}$ Department of Microbiology, Oregon State University, Corvallis, OR 97331, USA
}

\begin{abstract}
Galaxias maculatus (Jenyns, 1842) is a widespread freshwater fish and an important component of the economically important whitebait fisheries across the Southern Hemisphere. We report a new myxosporean parasite (Cnidaria: Myxozoa) infecting the kidney of G. maculatus from northwestern Patagonia (Argentina). Ortholinea lauquen sp. nov. was characterized using myxospore morphology, morphometrics and small subunit rDNA (ssrDNA) sequence data. Our ssrDNA phylogenetic analyses showed that $O$. lauquen sp. nov. is a member of the oligochaete-freshwater urinary tract clade and basal to a clade containing 4 different spore morphotypes (Chloromyxum, Myxidium, Zschokkella, Hoferellus). We explored host-parasite relationships at the macro- and microscale by analyzing the distribution, tissue tropism and pathology of $O$. lauquen sp. nov. Prevalence was relatively low $(7 \%)$ by microscopy, but PCR detection revealed hidden levels of infection (49\%), with the highest detection in lakes Morenito and Moreno (63-90\%, Río Negro Province). The only locality negative by both microscopy and PCR was the Caleufu River (Neuquén Province), suggesting differences in fish life history traits (landlocked vs. potamodromous) or preference of the putative obligate invertebrate host for lentic habitats. O. lauquen sp. nov. sporulates in the renal tubules and occasionally in the glomerular space. The plasmodia frequently occluded the tubule lumina, and cellular necrosis and disintegration of the epithelium were observed. O. lauquen sp. nov. could represent a potential threat to G. maculatus culture under intensive farming conditions.
\end{abstract}

KEY WORDS: Myxozoa · Galaxias maculatus · Ortholinea - Urinary system • South America · Patagonia · Histopathology

\section{INTRODUCTION}

Galaxias maculatus (Jenyns, 1842) (Osmeriformes: Galaxiidae; known as inanga by the Māori or puyen chico in Spanish) is one of the most naturally widely distributed freshwater fish (Berra et al. 1996). This amphidromous species is found throughout the Southern Hemisphere temperate zone, in coastal environments, rivers and lakes, with diadromous and landlocked populations, e.g. in the Andean lakes. $G$. maculatus is one of the species regarded as whitebait and is an important component of this commercial and recreational fishery as food fish in New Zealand and Chile (David et al. 2014, Froese \& Pauly 2018, Gomon \& Bray 2019). Studies have been undertaken on its biology and reproduction for commercial uses, 
as a laboratory animal, and for repopulation of habitats where the fish has been extirpated through overexploitation or depredation by introduced salmonids; research into culturing programs is known as galaxiculture (Mitchell 1989, Vega et al. 2013).

Myxozoans are a widespread group of parasitic cnidarians that have complex life cycles which alternate between an intermediate host (vertebrates, mainly fish) and a definitive host (annelid or bryozoan) (Eszterbauer et al. 2015). These spore-forming parasites are responsible for diseases that can cause significant impacts on fish health in both wild populations and aquaculture and affect commercial fisheries (Dyková \& Lom 1982, Molnár et al. 1989, Hedrick et al. 1993, Whipps 2011). The genus Ortholinea Shulman, 1962 contains some 20 species, which develop myxospores mostly in the excretory system of marine fishes. The known species form a polyphyletic group scattered through the oligochaete-freshwater urinary tract clade of myxozoans (Fiala 2006, Rangel et al. 2014, 2017, Holzer et al. 2018). This heterogeneous clade contains at least 7 different genera with very different spore morphologies. Several representatives from this clade were reported to cause disease and/or histopathological changes in the urinary system of their hosts (e.g. kidney enlargement disease in goldfish, Molnár et al. 1989; inter-renal disease in bluegill, Whipps 2011). Few data exist on the host-parasite interaction of members of the genus Ortholinea in the urinary system of their hosts.

Using general metazoan and/or myxozoan primers, we screened kidney samples of G. maculatus collected from 5 localities in northwestern Patagonia. We identified and characterized a novel Ortholinea species using myxospore morphology, morphometrics and small subunit rDNA (ssrDNA) sequence data. At macro- and microscales, we explored host-parasite relationships by studying the distribution of infections in G. maculatus populations from the different localities and pathology of the parasite where it sporulated in the kidney. The DNA data were used to determine phylogenetic relationships among our novel Ortholinea and other members of the oligochaete-freshwater urinary tract myxozoan clade.

\section{MATERIALS AND METHODS}

\subsection{Fish collection and dissection}

In 2017 and 2018, we collected 114 puyen chico from 5 localities in Patagonia, Argentina, comprising the Andean glacial lakes Moreno, Morenito, Escondido and Gutiérrez in Río Negro Province and the Caleufu River in the Patagonian steppe of Neuquén Province (Table 1). Fish were captured alive using hand nets and baited traps, transported in an aerated cooler to the Laboratorio de Parasitología (INBIOMA: CONICET-UNCo) and killed by neural pithing before dissection. We examined wet mounts of brain, gills, gall bladder and kidney for myxozoan parasites using a light microscope at 400 to $1000 \times$ magnification. This study focuses on the parasites found in the kidney. Kidney samples were preserved in ethanol for later DNA analyses or fixed for histology or electron microscopy.

\subsection{Morphological analysis of myxozoans}

Digital images of fresh myxozoan stages were obtained at $1000 \times$ magnification under bright field with a Zeiss AxioCamERc5s camera mounted on a Zeiss Primo Star compound microscope. Spore measurements followed published recommendations (Lom \& Arthur 1989; but using the more structurally accurate term polar tubule instead of polar filament, Ben-David et al. 2016). Measurements in micrometers were taken from the images using ImageJ $(\mathrm{v}$. 1.47, National Institutes of Health, Bethesda, MD, USA) and are presented as the mean followed by SD and range in parentheses. Parasite myxospores were air dried directly onto glass slides, stained with DiffQuik and mounted with DPX (Sigma-Aldrich). Archival smears and histological sections were deposited at the Invertebrate Collection of Museo de La Plata, FCNyM-UNLP, La Plata, Buenos Aires, Argentina.

For scanning electron microscopy (SEM), mature myxospores were washed out of one infected kidney with $0.1 \mathrm{M}$ cacodylate buffer and then fixed with glutaraldehyde to a final concentration of $2.5 \%$. The spores were left to settle on a $0.4 \mu \mathrm{m}$ Nucleopore filter (Whatman), dehydrated in a graded ethanol series for 15 min each step, and then critical point dried before being sputtercoated with gold:palladium (40:60 ratio). Myxospores were examined using an FEI Quanta 600 FEG scanning electron microscope at Oregon State University's Electron Microscopy Facility.

For histology, one infected kidney was fixed in $10 \%$ neutral buffered formalin, dehydrated in a graded alcohol series and then embedded in paraffin. Sections were cut at $6 \mu \mathrm{m}$ and stained with haematoxylin and eosin or Giemsa. 
Table 1. Ortholinea lauquen sp. nov. prevalence, as revealed by light microscopy and by PCR of Galaxias maculatus kidneys collected from northwestern Patagonia, and number of small subunit rDNA isolates sequenced, sequence lengths and GenBank accession numbers

\begin{tabular}{|c|c|c|c|c|c|c|}
\hline Locality & $\begin{array}{l}\text { Month and } \\
\text { year }\end{array}$ & $\begin{array}{l}\text { No. of } \\
\text { fish }\end{array}$ & $\begin{array}{c}\text { Prevalence } \\
\text { by microscopy }\end{array}$ & $\begin{array}{l}\text { Prevalence } \\
\text { by PCR }\end{array}$ & $\begin{array}{l}\text { No. of } \\
\text { sequences }\end{array}$ & $\begin{array}{l}\text { Sequence length and GenBank } \\
\text { accession no. }\end{array}$ \\
\hline \multirow{6}{*}{$\begin{array}{l}\text { Lake Morenito } \\
\left(41^{\circ} 3^{\prime} 17.17^{\prime \prime} \mathrm{S}\right. \\
\left.71^{\circ} 31^{\prime} 7.41^{\prime \prime} \mathrm{W}\right)\end{array}$} & July 2017 & 5 & $0 \%(0 / 5)$ & $100 \%(5 / 5)^{\mathrm{a}}$ & 5 & 685 bp (GM12_6; MN128726) \\
\hline & & & & & & 763 bp (GM12_8; MN128725) \\
\hline & & & & & & 763 bp (GM12_9; MN128724) \\
\hline & & & & & & 685 bp (GM12_10; MN128723) \\
\hline & January 2018 & 13 & $8 \%(1 / 13)$ & NA & - & - \\
\hline & November 2018 & 5 & $0 \%(0 / 5)$ & $80 \%(4 / 5)$ & 1 & - \\
\hline \multirow{4}{*}{$\begin{array}{l}\text { Lake Escondido } \\
\left(41^{\circ} 3^{\prime} 37.64^{\prime \prime} \mathrm{S}\right. \\
\left.71^{\circ} 33^{\prime} 58.86^{\prime \prime} \mathrm{W}\right)\end{array}$} & July 2017 & 10 & $0 \%(0 / 10)$ & $100 \%(9 / 9)^{a}$ & 9 & 750 bp (GM11_3; MN128728) \\
\hline & & & & & & 786 bp (GM12_4; MN128727) \\
\hline & March 2018 & 8 & $0 \%(0 / 8)$ & $25 \%(2 / 8)$ & - & - \\
\hline & November 2018 & 8 & $0 \%(0 / 8)$ & $50 \%(4 / 8)$ & 2 & - \\
\hline Lake Moreno & March 2018 & 20 & $15 \%(3 / 20)$ & $45 \%(9 / 20)$ & 4 & 2040 bp (GM3; MN128729) type \\
\hline $\begin{array}{l}\left(41^{\circ} 3^{\prime} 34.67^{\prime \prime} \mathrm{S}\right. \\
\left.71^{\circ} 33^{\prime} 50.82^{\prime \prime} \mathrm{W}\right)\end{array}$ & November 2018 & 12 & $25 \%(3 / 12)$ & $92 \%(11 / 12)$ & 1 & - \\
\hline $\begin{array}{l}\text { Caleufu River } \\
\left(40^{\circ} 23^{\prime} 52.94^{\prime \prime} \mathrm{S},\right. \\
\left.70^{\circ} 44^{\prime} 16.47^{\prime \prime} \mathrm{W}\right)\end{array}$ & March 2018 & 21 & $0 \%(0 / 21)$ & $0 \%(0 / 21)$ & - & - \\
\hline $\begin{array}{l}\text { Lake Guitérrez } \\
\left(41^{\circ} 10^{\prime} 37.32^{\prime \prime} \mathrm{S},\right. \\
\left.71^{\circ} 24^{\prime} 54.73^{\prime \prime} \mathrm{W}\right)\end{array}$ & November 2018 & 12 & $8 \%(1 / 12)$ & $42 \%(5 / 12)$ & - & - \\
\hline
\end{tabular}

\subsection{Molecular data and phylogenetic analyses}

Kidney tissues $(\mathrm{n}=100)$ preserved in $96-100 \%$ ethanol were first air dried, and then total DNA was extracted using a phenol-chloroform protocol (Holzer et al. 2004) or the DNeasy blood and tissue kit (Qiagen). Extracted DNA was re-suspended in 100-200 $\mu \mathrm{l}$ RNAse- and DNAse-free water. Kidney samples from July 2017 were screened using a fully nested PCR with a first round of primers ERIB1 (5'ACC TGG TTG ATC CTG CCA G-3') and ERIB10 (5'-CTT CCG CAG GTT CAC CTA CGG-3') (Barta et al. 1997) followed by MyxGP2F (5'-WTG GAT AAC CGT GGG AAA-3'; Kent et al. 1998) and Act1R (5'AAT TTC ACC TCT CGC TGC CA-3'; Hallett \& Diamant 2001). Samples from 2018 were screened in single round PCR using 18e (5'-CTG GTT GAT CCT GCC AGT-3'; Hillis \& Dixon 1991) and novel primer ACTATK1r (5'-ATG GAA ACG GTC TTG ACA AAT GCC-3'). Additional primers 18e and MYX4R (5'CTG ACA GAT CAC TCC ACG AAC-3'; Hallett \& Diamant 2001) were used to obtain the longest ssrDNA type sequence. PCRs were conducted in $10 \mu \mathrm{l}$ reactions with $2 \mathrm{U}$ Titanium Taq DNA polymerase and $10 \times$ buffer which contained $1.5 \mathrm{mM}$ $\mathrm{MgCl}_{2}$ (BD Biosciences Clontech), 0.5× RediLoad dye

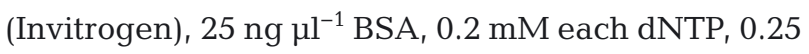
$\mu \mathrm{M}$ each primer, PCR-grade water and 10 to $150 \mathrm{ng}$ of template DNA or $1 / 6$ diluted $1^{\text {st }}$-round PCR product. ERIB1-ERIB10 PCR cycling conditions consisted of $95^{\circ} \mathrm{C}$ for $2 \mathrm{~min}$; followed by 35 cycles of $94^{\circ} \mathrm{C}$ for 50 $\mathrm{s}, 60^{\circ} \mathrm{C}$ for $1 \mathrm{~min} 20 \mathrm{~s}$ and $68^{\circ} \mathrm{C}$ for $2 \mathrm{~min}$; and a final extension at $68^{\circ} \mathrm{C}$ for $10 \mathrm{~min}$. All other PCR cycling conditions consisted of $95^{\circ} \mathrm{C}$ for $3 \mathrm{~min}$; followed by 35 cycles of $94^{\circ} \mathrm{C}$ for $20 \mathrm{~s}, 62^{\circ} \mathrm{C}$ for $20 \mathrm{~s}$ and $68^{\circ} \mathrm{C}$ for $25 \mathrm{~s}$; and a final extension at $68^{\circ} \mathrm{C}$ for $7 \mathrm{~min}$. DNA amplicons were visualized with a $1 \%$ agarose gel in sodium acetate or TAE buffer and then purified for sequencing using a Gel/PCR DNA fragments extraction kit (Geneaid Biotech) or a QIAquick PCR purification kit (Qiagen) or by direct sequencing of a diluted 1:10 PCR product. Sequences were obtained with an ABI PRISM 3130x1 or ABI3730 genetic analyzer sequencer (Applied Biosystems). We trimmed overlapping partial sequences of ssrDNA and assembled them into consensus contigs using Geneious 7.0.6. (Biomatters).

We used our longest contig, $2040 \mathrm{bp}$, in a BLAST search of GenBank to identify the closest relatives to our novel myxozoan (> $80 \%$ identity). We then downloaded available sequences of Ortholinea spp. and species of other related genera above this similarity 
threshold, all of which belonged to the oligochaetefreshwater urinary tract clade (Fiala 2006, Holzer et al. 2018). Basal myxozoans Myxidium lieberkuehni Bütschli, 1882 and Chloromyxum legeri Tourraine, 1931 were used as outgroup taxa. Alignment and phylogenetic analyses were performed with programs as plugins in Geneious 7.0.6. We aligned the sequence files using MAFFT v. 7.017, with the L-INSI algorithm and default parameters. We used the GTR + G substitution model, which was determined to be one of the best fitting models according to Modeltest (Posada \& Crandall 1998) using the FindModel web implementation: http://hiv.lanl.gov/content/sequence/ findmodel/findmodel.html. Phylogenetic analyses comprised maximum likelihood (ML) using RAxML v. 7.2.8 (Stamatakis et al. 2005), maximum parsimony (MP) using PAUP v. 4.0 (Swofford 2002) and Bayesian inference (BI) using MrBayes v. 3.2.6 (Ronquist \& Huelsenbeck 2003). ML and MP analyses were conducted using heuristic searches with random taxa addition, TBR swapping algorithm, all characters treated as unordered and gaps treated as missing data. Clade support values were calculated from 1000 bootstrap replicates for both ML and MP analyses. For BI, posterior probabilities were calculated over 1000000 generations via 2 independent runs of 4 simultaneous Markov chain Monte Carlo algorithms with every $200^{\text {th }}$ tree saved. Burn-in was set to 100000 generations. We calculated interspecific ssrDNA identity (\%) using PAUP v. 4.0 using $5^{\prime}$ and $3^{\prime}$ ends trimmed and removed inserts of $M$. streisingeri Whipps, Murray \& Kent, 2015 (GenBank Accession No. KM001684) from the alignment.

\section{RESULTS}

Of the 114 puyen chico collected, 32 were females, 16 were males and 66 were of undetermined sex, with average $( \pm \mathrm{SD})$ total length $5.3 \pm 1.3 \mathrm{~cm}$ and weight $0.9 \pm 0.9 \mathrm{~g}$. Myxozoan plasmodia and spores were found in the kidney of $7 \%(8 / 114)$ of the fish, and this is described as a new species from Galaxias maculatus, with a differential diagnosis.

\subsection{Ortholinea lauquen sp. nov. taxonomic summary}

Type host: G. maculatus (Jenyns, 1842).

Type locality: Lago Moreno ( $41^{\circ} 33^{\prime} 34.67^{\prime \prime} \mathrm{S}, 71^{\circ} 33^{\prime}$ 50.82" W), San Carlos de Bariloche, Río Negro, Argentina.
Site of infection: Renal tubules.

Prevalence: $7 \%$ (8/114) microscopic detection, $49 \%(49 / 100)$ molecular detection.

Etymology: From the word 'lauquen', meaning 'lake' in the language of the Mapuches, one of the indigenous peoples of Patagonia.

Material deposited: Invertebrate Collection of Museo de La Plata, FCNyM-UNLP, La Plata, Buenos Aires, Argentina; 2 Diff-Quik stained slides of airdried spores (Catalog Nos. MLP-Oi 4195 and MLP-Oi 4196) and 1 histological section of infected kidney (Catalog No. MLP 4197).

Molecular data: Partial ssrDNA sequence, $2040 \mathrm{bp}$ (GenBank Accession No. MN128729).

\subsection{Description of myxospores}

Based on 82 myxospores from the kidneys of 7 hosts and spores examined by SEM from 1 host. Myxospores subspherical (Figs. 1A-F \& 2), width $7.3 \pm 0.4(6.5-8.3) \mu \mathrm{m}$, length $7.6 \pm 0.4(6.6-8.8)$ $\mu \mathrm{m}$ (both in valvular view, $\mathrm{n}=47$ ) and thickness $7.5 \pm 0.6$ (6.3-8.8) $\mu \mathrm{m}$ (sutural view, $\mathrm{n}=35$ ). Two valves, joined at straight suture, with surface ridges 15 to 20, semi-concentric, some bifurcated, occupying entire myxospore surface (Fig. 1F). Polar capsules, 2, pyriform $3.3 \pm 0.3(2.2-4.0) \mu \mathrm{m} \times$ $2.4 \pm 0.3(1.8-3.1) \mu \mathrm{m}(\mathrm{n}=92)$ located towards one end of the spore, each in different valves, with openings in opposite directions (Figs. 1C \& 2), each capsule contains a coiled tubule with 3 to 4 turns. Sporoplasm binucleate.

\subsection{Description and tissue location of plasmodia}

Based on 14 plasmodia from 3 hosts. Amoeboid, spherical and pyriform plasmodia (Fig. 1G-H), $24.7 \pm$ $12.4(14.4-55.4) \mu \mathrm{m} \times 16.7 \pm 4.6(9.3-28.1) \mu \mathrm{m}$, in lumina of renal tubules. Occasionally multiple plasmodia occluded the lumina of renal tubules. Myxospores develop in pairs, 2 to 6 spores per plasmodium. Plasmodia with posterior pseudopodium.

\subsection{Remarks}

Based on myxospore and polar capsule shape, number of polar capsules and their position with respect to the straight sutural plane, we place the new species in the genus Ortholinea. Ortholinea lauquen sp. nov. is unique with respect to all other 

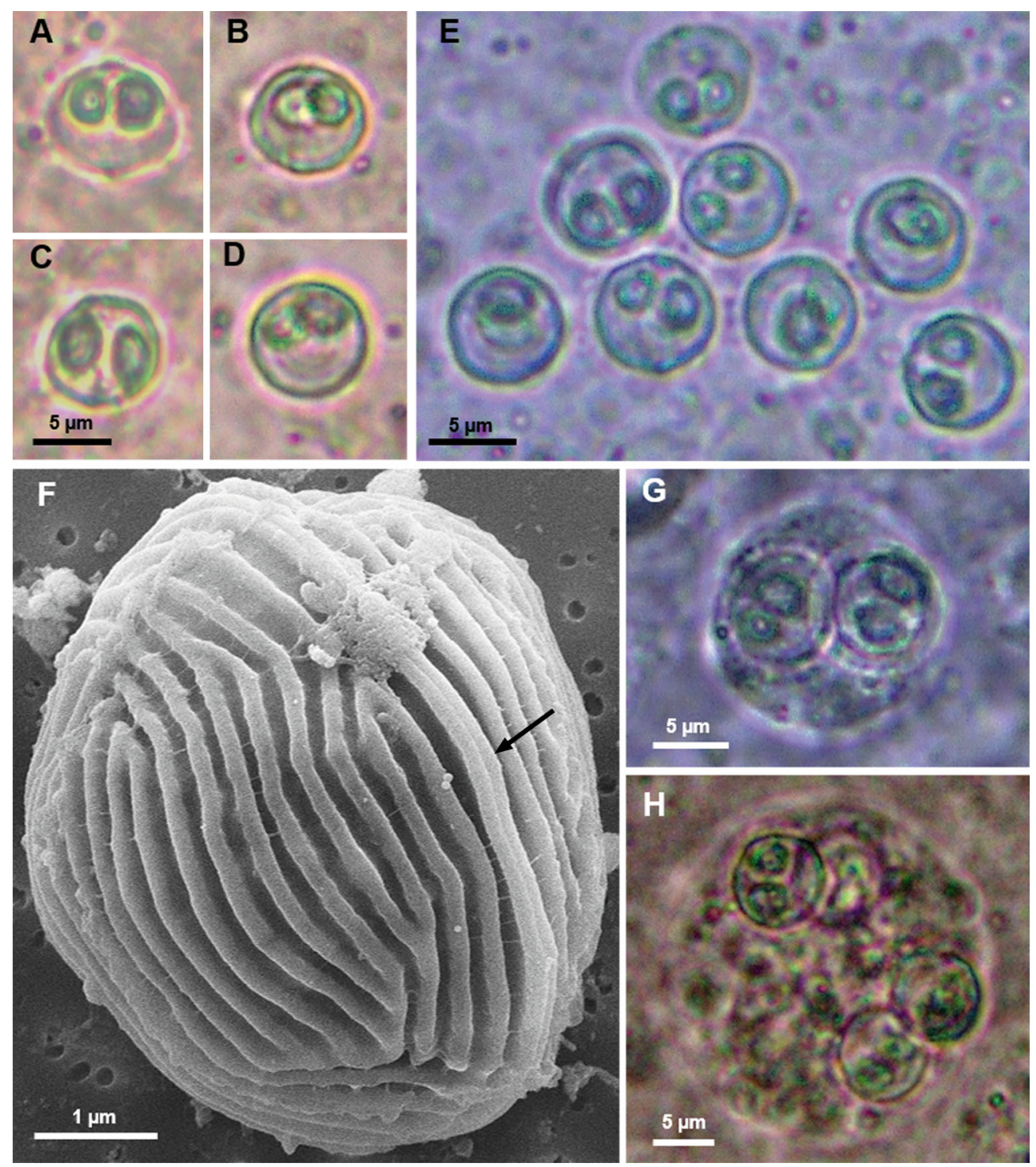

Fig. 1. Ortholinea lauquen sp. nov. myxospores and plasmodia (light microscopy and scanning electron microscopy) from the kidney of Galaxias maculatus. Myxospores in (A,B) side sutural view, (C) apical sutural view and (D) valvular view. (E) Group of mature myxospores in different orientations. (F) Scanning electron micrograph of myxospore showing ridges on surface of valve cell and prominent straight suture (arrow) between the 2 valve cells. Round plasmodia with (G) 2 or (H) 4 developing myxospores

Ortholinea species in fish host and geographic location (Table 2). It is morphologically and morphometrically similar to several members of the genus: $O$. labracis Rangel et al., 2017; O. africanus Abdel-Ghaffar et al., 2008; O. antipae Moshu \& Trombitsky, 2006; and O. gobiusi Naidenova, 1968, with the only difference being spore thickness and shape of the polar capsule (pyriform vs. subspherical or round) (Table 2). O. lauquen sp. nov. differed in spore width from O. clupeidae Aseeva, 2000. The new species is differentiated from O. fluviatilis Lom \& Dyková, 1995 and
O. undulans Meglitsch, 1970 by polar capsule shape (pyriform vs. subspherical) and the maximum number of polar tubule turns. O. lauquen sp. nov. and $O$. orientalis (Shulman \& Shulman-Albova 1953) from clupeid and gadid fishes can be distinguished by their disparate geographical distribution (Patagonia vs. Denmark and Bering Sea). Measurements of the myxospores of $O$. orientalis overlapped with $O$. lauquen sp. nov., but some differed in length (Shulman \& Shulman-Albova 1953, Aseeva 2000, 2002, Karlsbakk \& Køie 2011). 

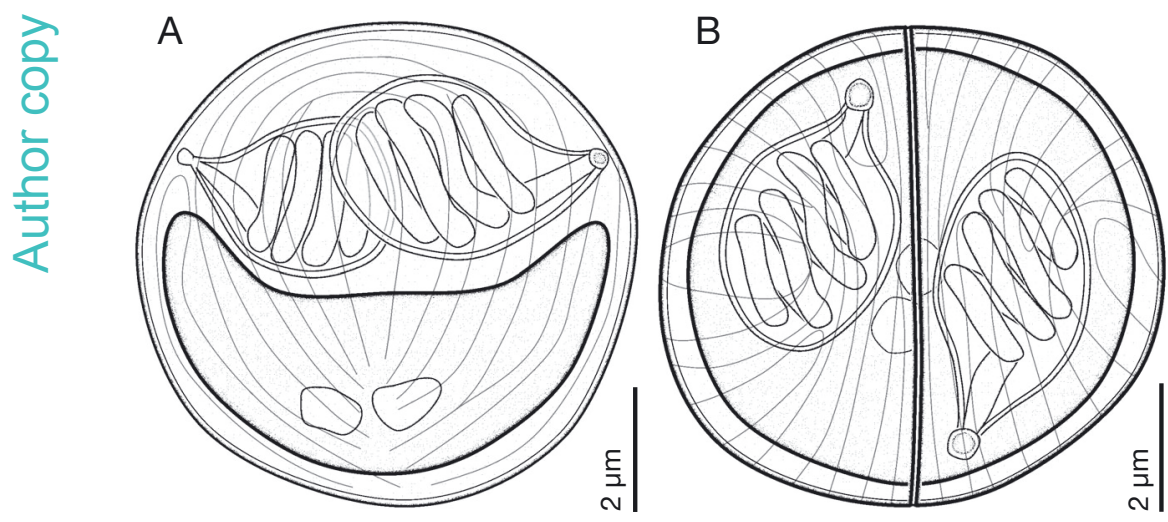

Fig. 2. Drawing of Ortholinea lauquen sp. nov. myxospore from Galaxias maculatus. (A) Valvular view; (B) apical sutural view. Surface ridges are represented schematically

Most Ortholinea spp. have been described with ornamentation of the outside of their valves, of different numbers and patterns of ridges. The number of ridges in O. lauquen sp. nov. is similar to O. concentrica Alama-Bermejo \& Hernández-Orts, 2018; $O$. auratae Rangel et al., 2014; O. striateculus Su \& White, 1994; and O. undulans. The species $O$. africanus, O. antipae, O. basma Ali, 2000 and O. australis Lom et al., 1992 all have fewer surface ridges than the new species (Table 2).

O. concentrica is the only other Ortholinea species described in Patagonia. The 2 Patagonian species differ in length, polar capsule shape (pyriform vs. subspherical) and host (freshwater G. maculatus vs. marine seabass Acanthistius patachonicus).

\subsection{Histopathology}

No gross clinical signs were observed. Plasmodia containing spores were located mostly in renal tubules (Fig. 3A), and occasionally spores were observed in the glomerular space (Fig. 3B). Plasmodia partially or completely adhered to the microvillar zone of the tubular epithelium and frequently occluded the lumina of the renal tubules (Fig. 3C-F). In some tubules, picnotic nuclei were observed at the base of the epithelium, suggesting cellular necrosis (Fig. 3C), and others showed epithelial disintegration associated with parasite stages (Fig. 3D). Swollen kidney tubules were observed frequently, with tubule epithelial cells enlarged with rounding of the plasma membrane (Fig. 3E) and apical blebbing (Fig. 3F), but swollen tubules were not associated with $O$. lauquen sp. nov. infection exclusively.

\subsection{Parasite prevalence}

By microscopy, we observed plasmodia and myxospores of $O$. lauquen sp. nov. in the lumina of G. maculatus kidney tubules at prevalences of $18.8 \%$ (6/32) in Lake Moreno, $8.3 \%(1 / 12)$ in Lake Guitérrez and $4.4 \%(1 / 23)$ in Lake Morenito; Lake Escondido (0/26) and the Caleufu River (0/21) were negative visually.

PCR detection (Table 1) revealed higher infection levels than visual detection in some localities. The highest PCR detection was $90.0 \%(9 / 10)$ in Lake Morenito, followed by $62.5 \%$ (20/32) in Lake Moreno, $60.0 \%$ (15/25) in Lake Escondido and 41.7 \% (5/12) in Lake Gutiérrez. Fish from Lake Escondido were positive by PCR only. The Caleufu River was the only locality negative by both microscopy and PCR.

\subsection{Molecular and phylogenetic results}

Partial ssrDNA sequences obtained in this study are listed in Table 1. In total, 23 isolates were obtained from $O$. lauquen sp. nov. from kidneys of different geographic locations. Intraspecific sequence identity was between 98.7 and 100\% (up to $9 \mathrm{bp}$ over a $656 \mathrm{bp}$ alignment). One isolate from Morenito Lake (July 2017) showed the highest variability (1.1-1.3\%, 7-9 bp different) (685 bp; GenBank Accession No. MN128723).

BLAST searches showed that the closest sequence matches of $O$. lauquen sp. nov. were $O$. auratae (GenBank Accession No. KR025869; query coverage $87 \%$; maximum identity $89 \%$ ) and O. labracis (GenBank Accession No. KU363831; query coverage $89 \%$; maximum identity $88 \%$ ).

Interspecific ssrDNA identities to members of the oligochaete-freshwater urinary tract clade (over an 835 bp alignment) varied widely. O. lauquen sp. nov. had the highest sequence similarity to Chloromyxum shurovi Shul'man \& Ieshko, 2003 (82.8\%), Myxidium giardi (Cépede, 1906) (82.7\%) and Zschokkella sp. ex Anguilla anguilla (L.) (82.7\%), followed by Ortholinea sp. ex Alosa alosa (L.) (82.6\%), O. orientalis (82.4\%) and Hoferellus alosae Wünnemann, Holzer, Pecková, Bartošová-Sojková, Eskens \& Lierz, 2016 $(82.4 \%)$. Sequence similarity to the only other species of Ortholinea described in Argentina, O. concentrica, was $78.7 \%$. 
형
한

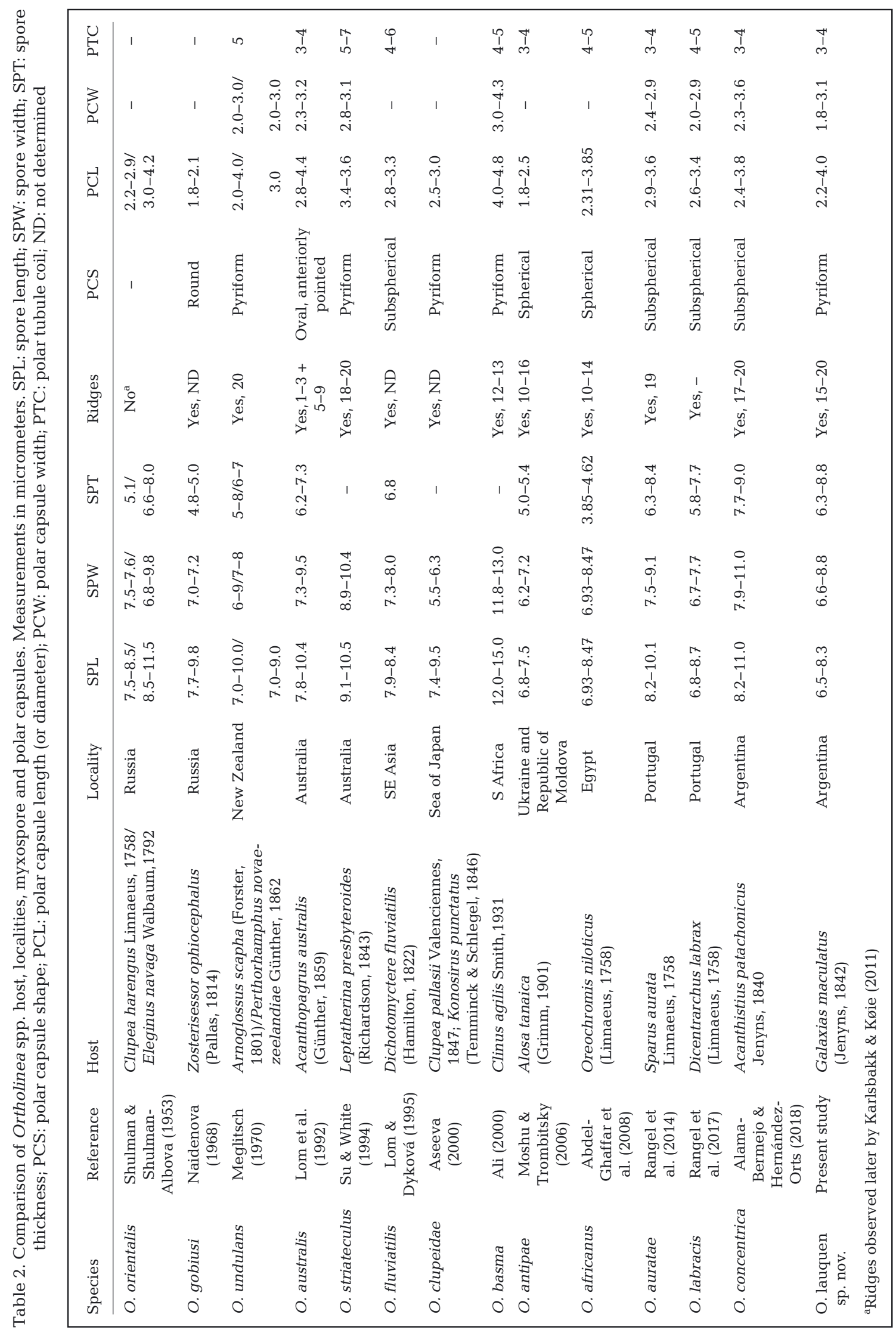



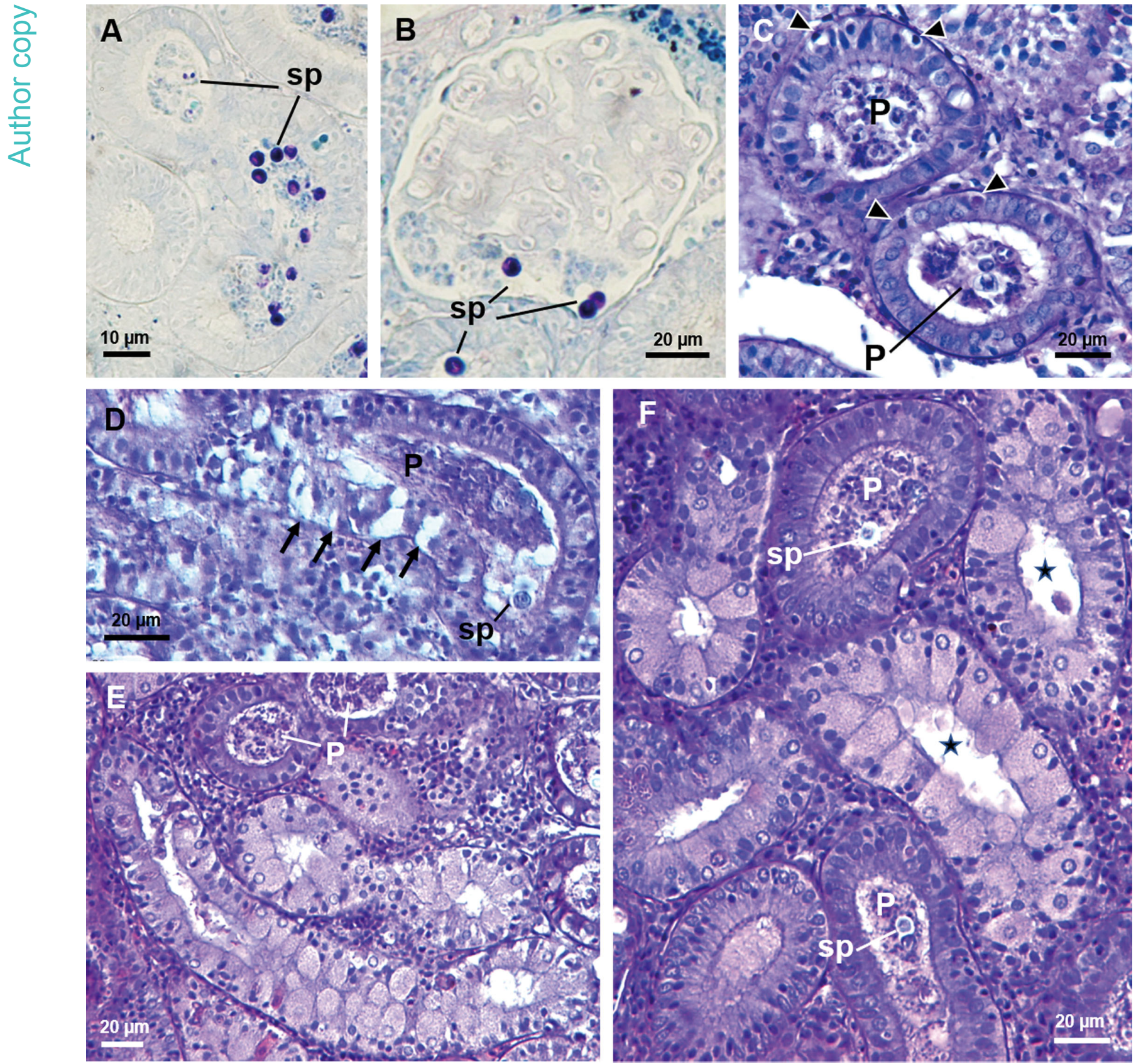

Fig. 3. Stained histological sections of Ortholinea lauquen sp. nov. from kidney of Galaxias maculatus. (A) Kidney tubules occluded by plasmodia and spores. (B) Spores in a glomerulus. (C) Plasmodia completely and partially attached to the microvillar zone of tubular epithelia, which have picnotic nuclei (arrowheads). (D) Kidney tubule with signs of epithelial disintegration (arrows) associated with the parasite. (E,F) Swollen kidney tubules, with enlarged epithelial cells showing rounded plasma membrane and apical blebbing (star). (A,B) Giemsa stain; (C-F) Haematoxylin-eosin stain. sp: spore; P: plasmodia (most with spores)

BI and MP phylogenetic analyses placed $O$. lauquen sp. nov. as basal taxa to a clade containing C. shurovi, M. giardi, Zschokkella sp. and H. azevedoi (Fig. 4). The position of the new species was unresolved using ML analyses.

\section{DISCUSSION}

Given the unique host, morphometrics, DNA sequence and phylogenetic position, we ascribed Ortholinea lauquen sp. nov. as a novel myxozoan 


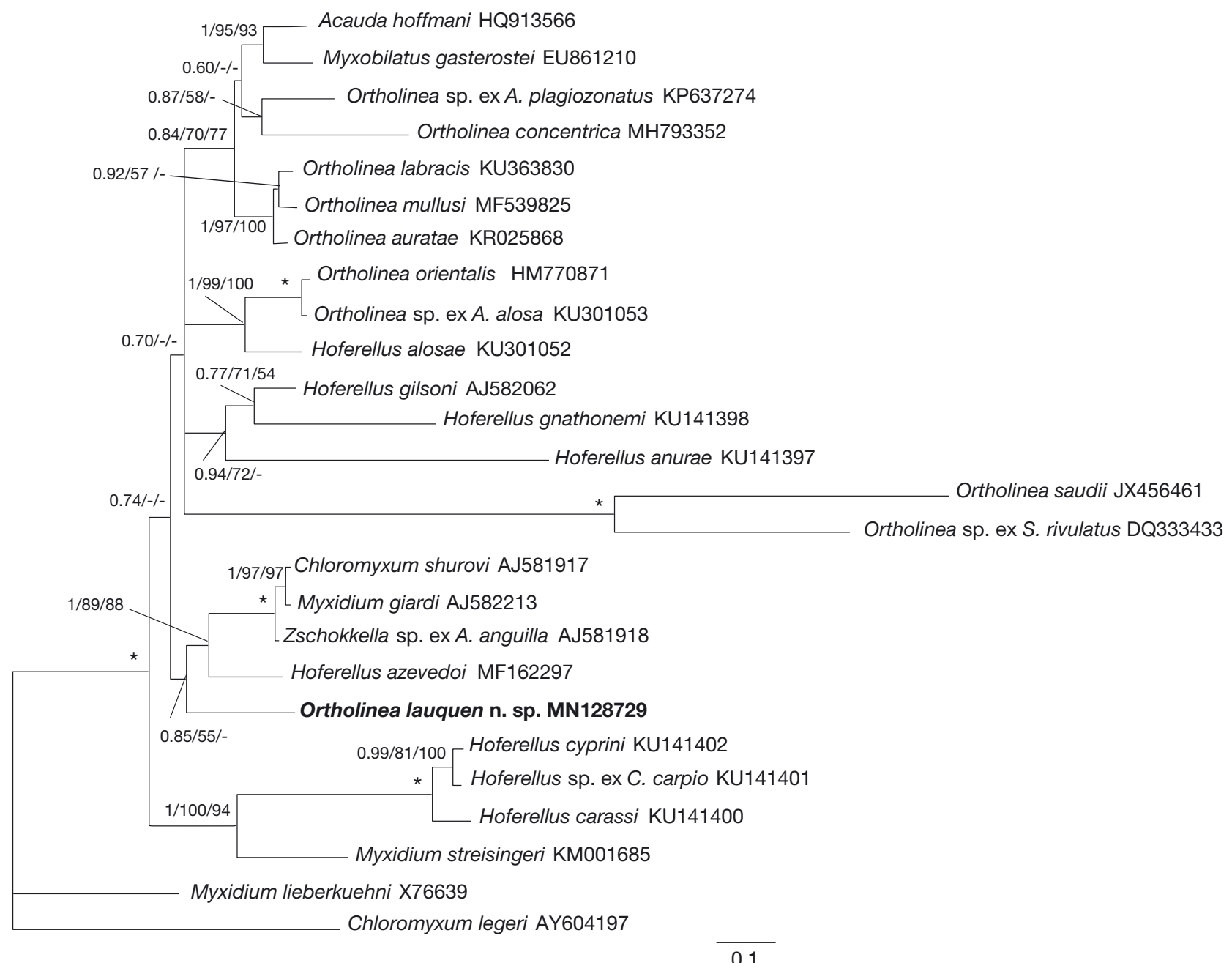

Fig. 4. Bayesian inference (BI) tree showing the phylogenetic position of Ortholinea lauquen sp. nov. within the oligochaetefreshwater urinary tract clade (as defined by Fiala [2006] and Holzer et al. [2018]). The new species is indicated in bold. Myxidium lieberkuehni and Chloromyxum legeri were used as outgroups. Numbers at nodes represent posterior probabilities and bootstrap values (BI/maximum likelihood [ML]/maximum parsimony [MP]). Asterisks indicate nodes with maximum supports $(\mathrm{BI}=1, \mathrm{MP} / \mathrm{ML}=100)$. Dashes at nodes represent nodal support $\mathrm{BI}<0.5$ and $\mathrm{MP} / \mathrm{ML}<50$ or node not present in the MP or ML trees

parasite of Galaxias maculatus and showed this to be the second species of Ortholinea described from Argentina. Five myxozoan species were known from G. maculatus: 4 Myxobolus spp. and Myxidium biliare Viozzi \& Flores, 2003, which sporulates in the gall bladder of G. maculatus in Patagonia, Argentina (Szidat 1953, Hine 1976, Kalavati et al. 2000, Flores \& Viozzi 2001, 2007, Viozzi \& Flores 2003). O. lauquen sp. nov. is the first myxozoan known to infect the urinary system of $G$. maculatus.

We detected a pattern of parasite prevalence in the fish populations, depending on sampled environment: all the infected fish were from oligotrophic lakes of glacial origin, and the only negative sample group was from a river. We consider several factors may con- tribute to this uneven prevalence. Different life histories of lake vs. river fish populations correlated with infection. Unlike the isolated lake populations, fish from the Calefu River have potamodromous migration (i.e. within freshwater), migrating from Piedra del Águila Reservoir to the river (Barriga et al. 2007); yet despite greater potential to encounter the parasite in different habitats, these river fish were infection free. Nothing is known about the putative invertebrate host of $O$. lauquen sp. nov., but we suspect it has a preference for lentic habitats. Further research is needed to understand the distribution of $O$. lauquen sp. nov. in water bodies of northwestern Patagonia and to identify if this correlates more with invertebrate rather than vertebrate host availability. 
The genus Ortholinea, like most myxozoan genera, was established on the basis of myxospore morphology (Lom \& Dyková 2006). The addition of molecular sequence data has shown the genus to be less cohesive, with phylogenetic analyses revealing Ortholinea to be polyphyletic, with species spread among multiple clades dominated by other genera or by species of mixed genera (Fiala 2006, Rangel et al. 2014, 2017, Alama-Bermejo et al. 2016). Our new species is further evidence of the polyphyletic nature of Ortholinea, with $O$. lauquen sp. nov. being less closely related to other Ortholinea and instead falling basal to a small clade of myxozoans with 4 different spore morphologies: Chloromyxum, Myxidium, Zschokkella, Hoferellus. Further morphological characterization of Ortholinea spores including ultrastructure is needed to determine if there are common morphological features among this myxozoan clade and to test the hypothesis that an Ortholinea morphotype is ancestral. Character evolution analyses by Fiala \& Bartošová (2010) suggest that a Chloromyxum morphotype represents the ancestral form, but Ortholinea species were not included in that analysis. Considering the morphology of Chloromyxum and Ortholinea myxospores, we speculate that Chloromyxum could be considered a twinned Ortholinea having double the valve cells and capsules but with similar distinctive valve cell surface ridges and phylogenetically basal positions. Given that myxospores with 4 valves are atypical for the majority of genera, we suggest that Ortholinea could represent the most ancestral freshwater form. Again, to test this hypothesis, Chloromyxum and Ortholinea species need to be reassessed at the ultrastructural level and combined in molecular and character evolutionary analyses.

Our histopathology analyses revealed that $O$. lauquen sp. nov. caused both physical and pathological changes to the host kidneys, with plasmodia occluding the tubule lumina and cellular necrosis and disintegration of the tubular epithelium. Similar signs of necrosis of the renal tubules have been reported for other urinary system-infecting myxozoans, and acute disease is observed with a few species (Molnár et al. 1989, Whipps 2011, Kodádková et al. 2014). Whether kidney damage caused by $O$. lauquen sp. nov. can manifest as disease, and if this can cause population-level impacts, is unknown. We have shown that the parasite is present at high prevalences in wild populations of puyen chico in northwestern Patagonian lakes; therefore, we suggest that given this high prevalence, the parasite could become a problem if other stressors are introduced. For example, if galaxiculture is established in this region, and cultured fish have similar prevalence of the parasite, the farming conditions may exacerbate the effects of $O$. lauquen sp. nov. infections, and disease could emerge. Future surveillance of the fish populations, particularly under localized stressful conditions (low water flow, higher temperatures), could reveal signs of population-level effects and inform risk assessments for this fish.

Acknowledgements. We thank Dr. Carlos Rauque (CONICET) for field sampling assistance, Teresa Sawyer at the OSU Electron Microscopy Facility for electron microscopy assistance, Dr. Jesús S. Hernández-Orts (CONICET) for assistance with spore illustration and LilyAna Folk (OSU) for PCR assays. We also thank Dr. Pavla Bartošová-Sojková (Biology Center CAS) for her comments on the phylogenetic analyses. Finally, we thank the following funding agencies: CONICET (PIP 112.201501.00477), Universidad Nacional del Comahue (Proyecto B-225 UNCo) and Czech Science Foundation (Grant Nos. 14-28784P and P505/12/G112). Samplings were carried out with permissions of the authorities of the National Parks Administration (No. 935), Neuquén Province (No. 7100-003467/17) and Subsecretaría de Medio Ambiente de la Municipalidad de Bariloche (No. 108AP-019).

\section{LITERATURE CITED}

Abdel-Ghaffar F, El-Toukhy A, Al-Quraishy S, Al-Rasheid K, Abdel-Baki AS, Hegazy A, Bashtar AR (2008) Five new myxosporean species (Myxozoa: Myxosporea) infecting the Nile tilapia Oreochromis niloticus in Bahr Shebin, Nile Tributary, Nile Delta, Egypt. Parasitol Res 103:1197-1205

Alama-Bermejo G, Hernández-Orts JS (2018) Ortholinea concentrica n. sp. (Cnidaria: Myxozoa) from the Patagonian seabass Acanthistius patachonicus (Jenyns, 1840) (Perciformes: Serranidae) off Patagonia, Argentina. Parasitol Res 117:3953-3963

Alama-Bermejo G, Jirk M, Kodádková A, Pecková H, Fiala I, Holzer AS (2016) Species complexes and phylogenetic lineages of Hoferellus (Myxozoa, Cnidaria) including revision of the genus: a problematic case for taxonomy. Parasit Vectors 9:13

Ali MA (2000) Ortholinea basma n. sp. (Myxozoa: Myxosporea) from agile klipfish Clinus agilis (Teleostei: Clinidae), light and scanning electron microscopy. Eur J Protistol 36:100-102

Aseeva NL (2000) Myxosporea from anadromous and coastal fishes from the northwestern Japan Sea. Izv TINRO 127:593-606 (in Russian)

Aseeva NL (2002) Myxosporidian fauna from Gadidae in the Far East Sea. Parazitologiia 36:167-174 (in Russian)

* Barriga JP, Battini MA, Cussac VE (2007) Annual dynamics variation of a landlocked Galaxias maculatus (Jenyns 1842) population in a northern Patagonian river: occurrence of juvenile upstream migration. J Appl Ichthyology 23:128-135

* Barta JR, Martin DS, Liberator PA, Dashkevicz M and others (1997) Phylogenetic relationships among eight Eimeria species infecting domestic fowl inferred using complete 
small subunit ribosomal DNA sequences. J Parasitol 83: 262-271

Ben-David J, Atkinson SD, Pollak Y, Yossifon G, Shavit U, Bartholomew JL, Lotan T (2016) Myxozoan polar tubules display structural and functional variation. Parasit Vectors 9:549

Berra TM, Crowley LELM, Ivantsoff W, Fuerst PA (1996) Galaxias maculatus: an explanation of its biogeography. Mar Freshw Res 47:845-849

David B, West D, Franklin P, Allibone R, Ling N, Hitchmough R, Crow S (2014) Galaxias maculatus. The IUCN Red List of Threatened Species 2014. www.iucnredlist.org/species/ 197279/2481214 (accessed on 7 January 2019)

* Dyková I, Lom J (1982) Sphaerospora renicola n. sp., a myxosporean from carp kidney, and its pathogenicity. Z Parasitenkd 68:259-268

Eszterbauer E, Atkinson S, Diamant A, Morris D, El-Matbouli M, Hartikainen H (2015) Myxozoan life cycles: practical approaches and insights. In: Okamura B, Gruhl A, Bartholomew J (eds) Myxozoan evolution, ecology and development. Springer, Cham, p 175-198

Fiala I (2006) The phylogeny of Myxosporea (Myxozoa) based on small subunit ribosomal RNA gene analysis. Int J Parasitol 36:1521-1534

Fiala I, Bartošová P (2010) History of myxozoan character evolution on the basis of rDNA and EF-2 data. BMC Evol Biol 10:228

Flores V, Viozzi G (2001) Redescription, seasonality, and distribution of Myxobolus magellanicus (Myxosporea) in Galaxias maculatus (Osmeriformes: Galaxiidae) from Patagonian Andean lakes (Argentina). Acta Parasitol 46: 159-163

Flores V, Viozzi G (2007) Infection of Myxobolus galaxii (Myxozoa) in Galaxias maculatus (Osmeriformes: Galaxiidae) from northwestern Patagonian Andean lakes (Argentina). J Parasitol 93:418-421

Froese R, Pauly D (eds) (2018) FishBase. www.fishbase.org (accessed 15 June 2018)

Gomon MF, Bray DJ (2019) Galaxias maculatus in fishes of Australia. http://fishesofaustralia.net.au/home/species/ 2129 (accessed on 8 January 2019)

Hallett SL, Diamant A (2001) Ultrastructure and small-subunit ribosomal DNA sequence of Henneguya lesteri n.sp. (Myxosporea), a parasite of sand whiting Sillago analis (Sillaginidae) from the coast of Queensland, Australia. Dis Aquat Org 46:197-212

* Hedrick RP, MacConnell E, de Kinkelin P (1993) Proliferative kidney disease of salmonid fish. Annu Rev Fish Dis 3: 277-290

Hillis DM, Dixon MT (1991) Ribosomal DNA: molecular evolution and phylogenetic inference. Q Rev Biol 66:411-453

Hine PM (1976) Myxobolus iucundus n. sp. (Sporozoa, Myxosporidea) parasitic in Galaxias maculatus (Jenyns, 1842) in New Zealand. J R Soc N Z 2:157-161

*Holzer AS, Sommerville C, Wootten R (2004) Molecular relationships and phylogeny in a community of myxosporeans and actinosporeans based on their 18S rDNA sequences. Int J Parasitol 34:1099-1111

KHolzer AS, Bartošová Sojková P, Born Torrijos A, Lövy A, Hartigan A, Fiala I (2018) The joint evolution of the Myxozoa and their alternate hosts: a cnidarian recipe for success and vast biodiversity. Mol Ecol 27: 1651-1666

Kalavati C, Brickle P, Mackenzie K (2000) Two new species of myxozoan parasites (Myxosporea, Multivalvulida, Bi- valvulida) from fishes of the Falkland Islands. Acta Parasitol 45:285-288

Karlsbakk E, Køie M (2011) Morphology and SSU rDNA sequences of Ortholinea orientalis (Shul'man and Shul'man-Albova, 1953) (Myxozoa, Ortholineidae) from Clupea harengus and Sprattus sprattus (Clupeidae) from Denmark. Parasitol Res 109:139-145

Kent ML, Khattra J, Hervio DML, Devlin RH (1998) Ribosomal DNA sequence analysis of isolates of the PKX myxosporean and their relationship to members of the genus Sphaerospora. J Aquat Anim Health 10:12-21

* Kodádková A, Dyková I, Tyml T, Ditrich O, Fiala I (2014) Myxozoa in high Arctic: survey on the central part of Svalbard archipelago. Int J Parasitol Parasites Wildl 3: $41-56$

Lom J, Arthur R (1989) A guideline for the preparation of species descriptions in Myxosporea. J Fish Dis 12: $151-156$

Lom J, Dyková I (1995) New species of the genera Zschokkella and Ortholinea (Myxozoa) from the Southeast Asian teleost fish, Tetraodon fluviatilis. Folia Parasitol (Praha) 42:161-168

* Lom J, Dyková I (2006) Myxozoan genera: definition and notes on taxonomy, life-cycle terminology and pathogenic species. Folia Parasitol (Praha) 53:1-36

Lom J, Rohde K, Dyková I (1992) Studies on protozoan parasites of Australian fishes. 1. New species of the genera Coccomyxa Léger et Hesse, 1907, Ortholinea Shulman, 1962 and Kudoa Meglitsch, 1947 (Myxozoa, Myxosporea). Folia Parasitol (Praha) 39:289-306

Meglitsch PA (1970) Some coelozoic myxosporida from New Zealand fishes: family Sphaerosporidae. J Protozool 17: 112-115

*Mitchell CH (1989) Laboratory culture of Galaxias maculatus and potential applications. N Z J Mar Freshw Res 23: 325-336

Molnár K, Fischer-Scherl T, Baska F, Hoffmann RW (1989) Hoferellosis in goldfish Carassius auratus and gibel carp Carassius auratus gibelio. Dis Aquat Org 7:89-95

Moshu AJ, Trombitsky ID (2006) New parasites (Apicomplexa, Cnidospora) of some Clupeidae fishes from the Danube and Dniestr basins. In: Academician Leo Berg 130: collection of scientific articles. Eco-TIRAS, Bendery, p 95-103

Naidenova NN (1968) Ortholinea gobiusi sp. nov. from Gobius ophiocephalus of the Black Sea. Biol Morya Kiev 14: 60-62 (in Russian)

* Posada D, Crandall KA (1998) MODELTEST: testing the model of DNA substitution. Bioinformatics 14:817-818

* Rangel LF, Rocha S, Borkhanuddin MH, Cech G and others (2014) Ortholinea auratae n. sp. (Myxozoa, Ortholineidae) infecting the urinary bladder of the gilthead seabream Sparus aurata (Teleostei, Sparidae), in a Portuguese fish farm. Parasitol Res 113:3427-3437

* Rangel LF, Rocha S, Casal G, Castro R and others (2017) Life cycle inference and phylogeny of Ortholinea labracis n. sp. (Myxosporea: Ortholineidae), a parasite of the European seabass Dicentrarchus labrax (Teleostei: Moronidae), in a Portuguese fish farm. J Fish Dis 40:243-262

Ronquist F, Huelsenbeck J (2003) MrBayes 3: Bayesian phylogenetic inference under mixed models. Bioinformatics 19:1572-1574

Shulman SS, Shulman-Albova RE (1953) Parasites of fishes of the White Sea. Akad Nauk SSSR, Moscow (in 


\section{Russian)}

Stamatakis A, Ludwig T, Meier H (2005) RAxML-III: a fast program for maximum likelihood-based inference of large phylogenetic trees. Bioinformatics 21:456-463

Su X, White RWG (1994) New myxosporeans (Myxozoa: Myxosporea) from marine fishes of Tasmania, Australia. Acta Protozool 33:251-259

Swofford DL (2002) PAUP* . Phylogenetic analysis using parsimony ( ${ }^{*}$ and other methods). Sinauer Associates, Sunderland, MA

Szidat L (1953) Einige neue Arten der Familie Myxobolidae Thelohan (Protozoa, Klase Sporozoa) aus Süßwasser-

Editorial responsibility: Dieter Steinhagen,

Hannover, Germany fischen Argentiniens. Gewasser Abwasser 5:7-16

Vega R, Dantagnan P, Mardones A, Valdebenito I, Zamorano J, Encina F (2013) Bases biológicas para el cultivo del puye Galaxias maculatus (Jenyns, 1842): una revisión. Lat Am J Aquat Res 41:369-386

*Viozzi GP, Flores VR (2003) Myxidium biliare sp. n. (Myxozoa) from gall bladder of Galaxias maculatus (Osmeriformes: Galaxiidae) in Patagonia (Argentina). Folia Parasitol 50:190-194

Whipps CM (2011) Interrenal disease in bluegills (Lepomis macrochirus) caused by a new genus and species of myxozoan. J Parasitol 97:1159-1165

Submitted: May 22, 2019; Accepted: July 19, 2019

Proofs received from author(s): September 20, 2019 